\title{
IZUZEĆA ZA VOZAČE I VOZILA - POSEBICE U ODNOSU NA PRIJEVOZ PUTNIKA NA LINIJSKIM VOŽNJAMA NA UDALJENOSTI DO 50 KILOMETARA ${ }^{3}$
}

\begin{abstract}
SAŽETAK
Izuzeća od primjene pojedinih odredbi o radnom vremenu, obveznim odmorima mobilnih radnika i uređajima za bilježenje u cestovnom prometu primjenjuju se na određene vozače koji upravljaju izuzetim skupinama vozila te na sama vozila koja su djelomično ili u cijelosti izuzeta od obveze ugradnje uređaja za bilježenje u cestovnom prijevozu - tahografa. U radu se kroz obradu i istraživanje odgovara na pitanje o kojim se točno izuzetcima radi te koji se sve izvori prava odnose na navedena izuzeća, primjenjuju li se ona u praksi i koje su novosti u njihovoj praktičnoj provedbi. Također se upućuje na izvore prava koji određuju radno vrijeme i obvezne odmore izuzetih vozača te način vođenja evidencije o takvim radnicima i njihovu radnom vremenu. Na kraju istraživanja ove tematike navode se prednosti i nedostatci primjene ovih izuzeća, kako za vozače, tako i za poslodavce te se daju zaključne ocjene o prednostima ovih izuzeća te potrebi dodatnih intervencija, kroz pravne akte, ali još više kroz praktično upoznavanje s pravima i obvezama vozača i poslodavaca, kako bi se otklonile nejasnoće i nesigurnosti kod ovih glavnih sudionika provedbe prijevoza robe i putnika u cestovnom prometu.
\end{abstract}

Ključne riječi: vozači, vozila, linijski prijevoz, izuzeća, radno vrijeme, evidencija

\section{UVOD}

Kada je u pitanju obavljanje prijevozničke djelatnosti i rad mobilnih radnika, vozača, jedno od temeljnih pitanja je pitanje njihovog radnog vremena i obveznih odmora te način na koji se ono evidentira. Sve vezano uz tahograf uređaje, kako u odnosu na vozače, tako i na vozila ne zauzima ništa manje pozornosti, a dodatno pitanje odnosi se na propisana izuzeća od primjene pojedinih odredbi koje se odnose na navedenu tematiku.

Pravna pravila koja se primjenjuju na organizaciju i provedbu usluga cestovnog prijevoza roba i putnika navedena su kroz pravne akte Europske unije te zakone i ostale pravne akte nacionalnog zakonodavstva. Za organizaciju rada i evidenciju radnog vremena vozača te uvjete za obavljanje usluga prijevoza roba i putnika u cestovnom prometu obvezujuća su u prvom redu dva zakonska

1 Bacc. ing. traff., student, Veleučilište u Rijeci, Vukovarska 58, 51000 Rijeka, Hrvatska.

E-mail: predsjednik@sindikatvozaca.hr

2 Dr. sc., predavač, Veleučilište u Rijeci, Vukovarska 58, 51000 Rijeka, Hrvatska.E-mail: sandra.debeljak@veleri.hr

3 Datum primitka rada: 15. 1. 2018.; datum prihvaćanja rada: 6. 3. 2018. 
akta, Zakon o prijevozu u cestovnom prometu (NN 82/13.) ${ }^{4}$ i Zakon o radnom vremenu, obveznim odmorima mobilnih radnika i uređajima za bilježenje u cestovnom prijevozu (NN 75/13., 36/15., 46/17.), ${ }^{5}$ a u pojedinim slučajevima primjenjivat će se Zakon o radu (NN br. 93/14., 127/17. $)^{6}$, kao temeljni propis kojim su uređeni radni odnosi u Republici Hrvatskoj. S obzirom na to da je tema ovoga rada vezana uz izuzeća od obveze uređenja radnog vremena i obveznih odmora mobilnih radnika i uređaja za bilježenje u cestovnom prijevozu, relevantni pravni izvori bit će obrađeni samo u pogledu izuzeća. Propisi koji reguliraju sigurnost prometa na cestama i tehničke uvjete vozila u cestovnom prijevozu također imaju svoju važnost u pogledu odredbi o ugradnji i korištenju tahograf uređaja pa će se i njihovom obradom usmjeriti samo na propisana izuzeća.

Povod za istraživanje i obradu izuzeća od odredbi o radnom vremenu, obveznim odmorima mobilnih radnika i uređajima za bilježenje u cestovnom prijevozu prije svega proizlazi iz neevidentirane, ali ipak nesporne činjenice da na području Republike Hrvatske gotovo nitko ne koristi predviđena izuzeća, a samim time niti ne koristi prava i olakšice koje proizlaze iz tih izuzeća.

U cestovnom prijevozu Republike Hrvatske svojom veličinom, brojem vozila i zaposlenih vozača prevladavaju prijevozničke tvrtke u sektoru cestovnog prijevoza putnika, dok se većina njihovog poslovanja zasniva na linijskom prijevozu putnika, koji se pak u velikom dijelu zasniva na linijskom prijevozu putnika na udaljenostima do 50 kilometara (https://www.dzs. hr). Ujedno je značajan dio njihova poslovanja usmjeren na prijevoz učenika te radnika na posao i s posla, što je definirano kao poseban linijski prijevoz putnika te u pogledu izuzeća izjednačeno s linijskim prijevozom putnika. Ovi posebni linijski prijevozi putnika uglavnom se odvijaju na relacijama koje su kraće od 50 kilometara.

Budući da je linijski prijevoz putnika na udaljenosti do 50 kilometara iznimno zastupljen na području Republike Hrvatske te da postoje tvrtke koje se isključivo bave tim prijevozom na koji se odnose i primjenjuju pojedina izuzeća koja su predmet istraživanja ovoga rada, a niti jedna od tih tvrtki ne koristi omogućena izuzeća, kroz ovaj rad poseban naglasak bit će stavljen upravo na linijski prijevoz putnika do 50 kilometara.

Kroz rad će se prikazati da se iznimke u pogledu vozača i vozila kojima ti vozači upravljaju ne podudaraju u potpunosti, odnosno da u određenim slučajevima postoje izuzeća za

4 U daljnjem tekstu Zakon o prijevozu u cestovnom prometu.

5 U daljnjem tekstu Zakon o radnom vremenu, obveznim odmorima mobilnih radnika i uređajima za bilježenje u cestovnom prijevozu ili Zakon.

6 U daljnjem tekstu Zakon o radu.

7 Navedeno je definirano čl. 4. st. 1. t. 29. Zakona o prijevozu u cestovnom prometu te proizlazi iz čl. 8. st. 1. Zakona o radnom vremenu, obveznim odmorima mobilnih radnika i uređajima za bilježenje u cestovnom prijevozu koji govori o linijskom prijevozu putnika. Isto naglašava resorno Ministarstvo u svojem mišljenju od 21. kolovoza 2017. godine: „(...) mišljenja smo da se javni linijski prijevoz i posebni linijski prijevoz putnika smatraju linijskim vožnjama u smislu primjene odredbi socijalnog zakonodavstva u cestovnom prijevozu. (...) Vozači vozila kojima se obavlja poseban linijski prijevoz putnika do $50 \mathrm{~km}$ su izjednačeni s vozačima vozila kojima se obavlja linijski prijevoz putnika do 50 kilometara u pogledu ZRVMR-a (...). Vozila kojima se obavlja posebni linijski prijevoz putnika na udaljenosti do 50 km izjednačena su s vozilima kojima se obavlja linijski prijevoz putnika do 50 km (...)" (Ministarstvo mora, prometa i infrastrukture, 2017 b). 
vozače, ali ne i za vozila. Navedene razlike vezane su uz posebnosti pojedinih vrsta prijevoza, odnosno kategorija vozila kojima se ti prijevozi obavljaju, no čini se da proizlaze i iz promjena nacionalnog zakonodavstva prvenstveno usmjerenih u pravcu usklađivanja nacionalnog zakonodavstva s onim Europske unije, a ne i sustavnog pristupa koji će dovesti do jasnog i potpunog definiranja ovih važnih određenja.

Cilj je ovog istraživanja prikazati važeće pravne izvore vezane uz propisana izuzeća za vozače i vozila i jasno definirati koji su to vozači izuzeti iz obveze uređenja radnog vremena, dozvoljenog vremena vožnje, obveznih odmora i vođenja evidencije o radnom vremenu vozača putem uređaja za bilježenje u cestovnom prijevozu te jasno navesti vozila koja su izuzeta iz obveze ugradnje uređaja za bilježenje radnog vremena u cestovnom prijevozu.

Prednosti i nedostaci izuzeća koji će činiti rezultate istraživanja ove tematike trebali bi potaknuti sve eventualno zainteresirane vozače i poslodavce da obrate pozornost na prednosti koje ostvaruju temeljem toga što su izuzeti iz primjene pojedinih odredbi o radnom vremenu, obveznim odmorima mobilnih radnika i uređajima za bilježenje u cestovnom prijevozu te jednako tako na nedostatke temeljem kojih će lakše donijeti odluku o tome hoće li koristiti omogućena im prava ili ne.

\section{IZVORI PRAVA VEZANI UZ PROPISANA IZUZEĆA ZA VOZAČE I VOZILA}

\section{1 Uredba (EZ) br. 561/2006}

Od travnja 2007. godine u Europskoj uniji primjenjuju se nova pravila vezana uz vrijeme vožnje vozača u cestovnom prijevozu. Ova pravila definirana su Uredbom (EZ) br. 561/2006 Europske unije iz 2006. godine (Prescott-Gagnon, Desaulniers, Drexl, Rousseau, 2010).

Uredba (EZ) br. 561/2006 donesena je radi utvrđivanja pravila o vremenu vožnje, stankama i razdobljima odmora vozača koji obavljaju cestovni prijevoz robe i putnika, kako bi se u prvom redu poboljšali radni uvjeti ovih kategorija radnika, a time i sigurnost cestovnog prometa. (čl. 1. i preambula Uredbe (EZ) br. 561/2006). ${ }^{9}$ Obvezna je za sve zemlje članice EU-a i svojim odredbama ima velik praktični značaj, posebno u odnosu na organizaciju, odnosno planiranje aktivnosti samih vozila, ograničavajući maksimalno vrijeme vožnje (Meyer, Kopfer, 2008).

8 Uredba (EZ) br. 561/2006 Europskog parlamenta i Vijeća od 15. ožujka 2006. o usklađivanju određenog socijalnog zakonodavstva koje se odnosi na cestovni promet i o izmjeni uredbi Vijeća (EEZ) br. 3821/85 i (EZ) br. 2135/98 te o stavljanju izvan snage Uredbe Vijeća (EEZ) br. 3820/85 (SL L 102, 11. 4. 2006.); u daljnjem tekstu: Uredba (EZ) br. $561 / 2006$.

9 Pravila vezana uz vrijeme vožnje, stanke i razdoblja odmora detaljno su propisana člancima 6. do 9. ove Uredbe, prema kojima je propisano najdulje dopušteno dnevno vrijeme vožnje u trajanju od 9 sati, koje može biti produljeno na 10 sati, ali ne više od dva puta tjedno. Najdulje dopušteno tjedno vrijeme vožnje propisano je u trajanju od 56 sati, a najdulje ukupno zbrojeno vrijeme vožnje tijekom bilo koja dva uzastopna tjedna u trajanju od 90 sati. Nakon razdoblja vožnje od 4 i pol sata, vozač mora uzeti neprekinutu stanku od najmanje 45 minuta, osim ako uzima razdoblje odmora. Predviđeno je najkraće dnevno razdoblje odmora u trajanju od 11 sati, koje se može smanjiti na 9 sati, ali ne više od 3 puta tjedno te redovito tjedno razdoblje odmora u trajanju od najmanje 45 sati i smanjeno tjedno razdoblje odmora u trajanju od najmanje 24 sata. (Vrijeme vožnje u sektoru cestovnog prometa, http://eur-lex.europa.eu/legal-content/HR/LSU/?uri=CELEX:32006R0561, 22. 2. 2018.) 
Poduzetnici koji se bave cestovnim prijevozom u obvezi su organizirati rad svojih vozača na način da se poštuju pravila ove Uredbe. Za nepoštovanje njezinih odredbi sa strane vozača jednako je odgovoran i njegov poslodavac, a Uredba zahtijeva da svi koji su uključeni u cestovni prijevozni proces, prijevozna poduzeća, otpremnici, špediteri, organizatori putovanja, kooperanti, pa čak i agencije za zapošljavanje vozača jamče da sporazumno ugovoreni vremenski rasporedi vožnji budu u skladu s ovom Uredbom (Kok et. al., 2010; čl. 10. st. 4. Uredbe (EZ) br. 561/2006).

Uredba (EZ) br. 561/2006 primjenjuje se na cestovni prijevoz tereta u kojem najveća dopuštena masa vozila, uključujući i priključno vozilo, prelazi 3,5 tona te cestovni prijevoz putnika vozilima koja su konstruirana ili trajno prilagođena za prijevoz više od devet osoba uključujući vozača te su namijenjena u tu svrhu. Njezina primjena odnosi se na cestovni prijevoz isključivo unutar EU-a ili između EU-a, Švicarske i država Europskog gospodarskog prostora, bez obzira na zemlju registracije vozila (čl. 2. Uredbe (EZ) br. 561/2006).

U članku 3. Uredba (EZ) br. 561/2006 propisuje da se ne primjenjuje na cestovni prijevoz koji obavljaju sljedeća vozila:

(a) vozila koja se koriste za prijevoz putnika na linijskim vožnjama na udaljenosti do 50 kilometara;

(b) vozila čija najveća dopuštena brzina ne prelazi 40 kilometara na sat;

(c) vozila koja su u vlasništvu ili najmu oružanih snaga, civilne zaštite, vatrogasnih službi ili snaga za održavanje javnog reda, bez vozača, ako je prijevoz koji se obavlja vezan uz zadaće koje su dodijeljene tim službama te se obavljaju pod njihovom kontrolom;

(d) vozila, uključujući i vozila koja se koriste u nekomercijalnom prijevozu humanitarne pomoći u hitnim intervencijama ili operacijama spašavanja;

(e) specijalizirana vozila koja se koriste u medicinske svrhe;

(f) specijalizirana vozila tehničke pomoći na cesti u slučaju kvara u radijusu od 100 kilometara od njihovog sjedišta;

(g) vozila koja se na cesti testiraju u svrhe tehničkog razvoja, popravaka ili održavanja te nova ili obnovljena vozila koja još nisu u funkciji;

(h) vozila ili kombinacije vozila s najvećem dopuštenom masom koja ne prelazi 7,5 tona, a koriste se za nekomercijalni prijevoz tereta;

(i) komercijalna vozila, koja imaju povijesni status u skladu sa zakonodavstvom države članice u kojoj se njima upravlja te se koriste za nekomercijalan prijevoz putnika ili tereta.

Vozila kojima se obavlja linijski prijevoz putnika na udaljenosti do 50 kilometara od posebnog su značaja za ovaj rad te je iz prethodnog određenja vidljivo kako su ista jasno navedena u području na koje se ne primjenjuje ova Uredba. To, međutim, ne znači da linijski prijevoz putnika nije obuhvaćen interesom ove Uredbe, jer ona navodi da bi države članice trebale utvrditi pravila za vozila koja se koriste u prijevozu putnika na redovitim linijama udaljenosti do 50 kilometara. Ta bi 
pravila trebala osigurati odgovarajuću zaštitu u vezi s dozvoljenim vremenom vožnje te obaveznih razdoblja prekida vožnje i odmora (Preambula Uredbe (EZ) br. 561/2006).

Uredbom (EZ) br. 561/2006 u poglavlju IV. 'Iznimke' propisano je da država članica može predvidjeti dulje maksimalne stanke i razdoblja odmora ili kraća maksimalna vremena vožnje od onih utvrđenih ovom Uredbom (u njezinim člancima 6. do 9.), ako se cestovni prijevoz u cijelosti odvija na njezinom području. U tom slučaju države članice uzimaju u obzir relevantne kolektivne ili druge ugovore između socijalnih partnera. No, treba naglasiti da se ova Uredba i dalje primjenjuje na vozače koji sudjeluju u međunarodnom prometu (čl. 11. Uredbe (EZ) br. 561/2006).

Kada je riječ o iznimkama iz članka 13. ove Uredbe, Republika Hrvatska je kroz Zakon o radnom vremenu i obveznim odmorima mobilnih radnika i uređaja za bilježenje u cestovnom prijevozu i njegov članak 8. stavak 3. u cijelosti prihvatila iznimke navedene u članku 13. Uredbe (EZ) br. 561/2006 koje se odnose na izuzeće od primjene ove Uredbe na:

(a) vozila koja su u vlasništvu ili su ih iznajmila, bez vozača, tijela javne vlasti za obavljanje cestovnog prijevoza koji ne predstavlja konkurenciju privatnim prijevoznicima;

(b) vozila koja koriste ili su ih iznajmila, bez vozača, poljoprivredna, hortikulturna, šumarska, stočarska ili ribarska poduzeća za prijevoz tereta za potrebe svoje vlastite poduzetničke djelatnosti u krugu do 100 km od sjedišta poduzeća;

(c) poljoprivrednih i šumarskih vozila za vuču koja se koriste za poljoprivredne ili šumarske djelatnosti, u krugu do 100 km od sjedišta poduzeća koje vozilo ima u vlasništvu, najmu ili zakupu;

(d) vozila ili skupovi vozila najveće dopuštene mase koja ne prelazi 7,5 tona te ih koriste:

- univerzalni pružatelji usluga definirani u članku 2. stavku 13. Direktive 97/67/ EZ Europskog parlamenta i Vijeća od 15. prosinca 1997. o zajedničkim pravilima za razvoj unutarnjeg tržišta poštanskih usluga Zajednice i poboljšanje kvalitete usluge radi dostave pošiljaka u sklopu univerzalne usluge, ili

- za prijevoz materijala, opreme ili strojeva koje vozač koristi tijekom svog posla.

Takva se vozila koriste samo unutar kruga od 50 kilometara od sjedišta poduzeća i pod uvjetom da upravljanje vozilima ne predstavlja glavnu djelatnost vozača;

(e) vozila koja se koriste isključivo na otocima čija površina nije veća od 2300 kvadratnih kilometara te koji nisu povezani s ostatkom nacionalnog područja mostom, gazom ili tunelom otvorenim za motorna vozila;

(f) vozila koja se koriste za prijevoz tereta u krugu od 50 kilometara od sjedišta poduzeća, na pogon zemnim ili ukapljenim plinom ili na električni pogon najveće dopuštene mase koja, uključujući masu prikolice ili poluprikolice, ne prelazi 7,5 tona;

(g) vozila koja se koriste za obuku vozača i provođenje ispita s ciljem stjecanja vozačke dozvole ili svjedodžbe o stručnoj osposobljenosti, pod uvjetom da se ne koriste za komercijalan prijevoz tereta ili putnika; 
(h) vozila koja se koriste za potrebe odvodnje, zaštite od poplava, službi opskrbe vodom, plinom i električnom strujom, održavanja i nadzora cesta, skupljanja i odlaganje komunalnog otpada kućanstava, telegrafskih i telefonskih službi, emitiranja radijskog i televizijskog programa i otkrivanja radijskih ili televizijskih odašiljača ili prijamnika;

(i) vozila s 10 do 17 sjedala koja se isključivo koriste za nekomercijalan prijevoz putnika;

(j) vozila specijalizirana za prijevoz opreme za cirkuse i zabavne parkove;

(k) posebno opremljena mobilna projektna vozila čija je prvenstvena namjena korištenje u stanju mirovanja kao edukacijskog objekta;

(I) vozila koja se koriste za prikupljanje mlijeka s gospodarstava i za povrat gospodarstvima kontejnera za mlijeko ili mliječnih proizvoda koji se koriste kao hrana za životinje;

(m) specijalizirana vozila za prijevoz novca i/ili dragocjenosti;

(n) vozila koja se koriste za prijevoz životinjskog otpada ili lešina koji nisu namijenjeni za prehranu ljudi;

(o) vozila koja se isključivo koriste na cestama unutar prometnih objekata kao što su luke, prekrcajne luke i željeznički terminali;

(p) vozila koja se koriste za prijevoz živih životinja s gospodarstava do lokalnih tržnica i natrag $\mathrm{s}$ tržnica u lokalne klaonice u krugu do $50 \mathrm{~km}$.

Naime, za navedena vozila Uredba (EZ) br. 561/2006 propisuje mogućnost da svaka država članica, ne dovodeći u pitanje temeljne ciljeve utvrđene Uredbom, ${ }^{10}$ može odobriti iznimke od članaka 5. do 9. Uredbe te zahtijevati da te iznimke podliježu pojedinačnim uvjetima na njezinom vlastitom području ili, u dogovoru s državama na koje se to odnosi, na području druge države članice. (čl. 13. Uredbe (EZ) br. 561/2006). Te iznimke odnose se na mogućnost da država članica odobri iznimke od onih odredaba Uredbe koje propisuju minimalnu dob vozača (iz članka 5. Uredbe), ${ }^{11}$ dnevna i tjedna vremena vožnje, stanke i razdoblja odmora (iz članaka 6. do 9. Uredbe). ${ }^{12} \mathrm{O}$ navedenim će se iznimkama dodatno govoriti u nastavku, obradom relevantnog nacionalnog pravnog akta.

\section{2 Uredba (EU) br. 165/2014}

Uredba (EZ) br. 561/2006 izmijenjena je Uredbom (EU) br. 165/2014, ${ }^{13}$ kojom se utvrđuju obveze i zahtjevi koji se odnose na izradu, ugradnju, uporabu, ispitivanje i provjeru uređaja za bilježenje

10 Radi se o cilju usklađivanja uvjeta tržišnog natjecanja između različitih oblika kopnenog prometa, posebno u odnosu na cestovni sektor te cilju poboljšanja radnih uvjeta rada i sigurnosti cestovnog prometa. Također i promicanju poboljšanih praksi nadzora i provedbe od strane država članica te poboljšanih radnih praksi u djelatnosti cestovnog prometa (čl. 1. Uredbe (EZ) br. 561/2006).

11 Prema članku 5. ove Uredbe, minimalna dob za vozača i suvozača je 18 godina, uz mogućnost da u nekim slučajevima minimalna dob za suvozača iznosi 16 godina.

12 Sukladno prikazanom određenju u bilješci 6 ovog rada.

13 Uredba (EU) br. 165/2014 Europskog parlamenta i Vijeća od 4. veljače 2014. o tahografima u cestovnom prometu, stavljanju izvan snage Uredbe Vijeća (EEZ) br. 3821/85 o tahografu u cestovnom prometu i izmjeni Uredbe (EZ) 
podataka (tahografa) koji se koristi u cestovnom prometu (čl. 1. Uredbe (EU) br. 165/2014).

Tahografi moraju biti ugrađeni u svim vozilima iznad 3,5 tone za prijevoz robe cestom i u vozila za prijevoz više od devet osoba (uključujući vozača), uz određene iznimke. Državama se ostavlja mogućnost da izuzmu od primjene ove Uredbe određene kategorije vozila (čl. 3. Uredbe (EU) br. 165/2014; Tahografi u cestovnom prometu, http://eur-lex.europa.eu; 20. 1. 2018.).

Primjena tahografa u cestovnim motornim vozilima ima svakako višestruko pozitivno značenje i pozitivne posljedice. Tahografski uređaj tako omogućuje praćenje rada vozača s obzirom na trajanje upravljanja vozilom, prijeđeni put, brzinu kretanja, vrijednosti i učestalosti usporenja i ubrzanja vozilom, kao i vrijeme odmora tijekom izvršavanja radnih zadataka, što je posebno bitno za sigurnost svih sudionika u prometnom sustavu (Rajsman, Rođak, 2015).

Jedno od zanimljivih rješenja Uredbe (EU) br. 165/2014 odnosi se na tahografe u vozilima koja će se prvi puta registrirati od 15. lipnja 2019., a koji moraju biti spojeni na satelitski navigacijski sustav i opremljeni tehnologijom za daljinsku komunikaciju kako bi se olakšale ciljane provjere na cesti. Zemlje EU-a imaju petnaest godina od 15. lipnja 2019. kako bi opremile svoja nadzorna tijela za takvu komunikaciju. Podaci mogu biti pohranjeni samo za vrijeme trajanja provjere na cesti, a moraju se izbrisati u roku od tri sata, osim ako je došlo do zloupotrebe tahografa (Tahografi u cestovnom prometu, http://eur-lex.europa.eu; 20. 1. 2018.)

Za temu ovog rada posebno je značajno pitanje područja primjene Uredbe (EU) br. 165/2014 vezano uz ugradnju i korištenje tahografa u vozilima kojima se obavlja prijevoz putnika na relacijama do 50 kilometara. Kako se sukladno ovoj Uredbi obveza ugradnje i korištenja tahografa proteže na ona vozila na koja se primjenjuje Uredba (EZ) br. 561/2006, u članku 3. stavku 1. Uredba (EU) br. 165/2014, između ostaloga, isključuje svoju primjenu na vozila registrirana u državama članicama kojima se obavlja ova vrsta prijevoza. Ovdje ne treba zaboraviti niti sve druge vrste vozila navedene u članku 3. Uredbe (EZ) br. 561/2006, kao što su ona čija najveća dopuštena brzina ne prelazi 40 kilometara na sat i druga.

Kako bi odredbe Uredbe (EU) br. 165/2014 u pogledu njezine (ne)primjene na vozila koja se koriste za prijevoz putnika na linijskim vožnjama na udaljenosti do 50 kilometara bile što jasnije, dodatno će se prikazati i kod domaćeg podzakonskog akta koji se bavi ovim pitanjima.

\subsection{Zakon o radnom vremenu, obveznim odmorima mobilnih radnika i uređajima za bilježenje u cestovnom prijevozu}

Na mobilne radnike - vozače zbog posebnosti njihovog posla primjenjuju se odredbe posebnog zakona koji regulira njihovo radno vrijeme, obvezne odmore i način na koji su o tome dužni voditi odgovarajuću evidenciju. Važeći Zakon o radnom vremenu, obveznim odmorima mobilnih radnika i uređajima za bilježenje u cestovnom prometu, koji je donesen 2013. te izmijenjen i dopunjen 2015. godine, usklađen je s odgovarajućim direktivama i uredbama EU-a, koje svoj regulativni temelj nalaze u tzv. AETR sporazumu donesenom još 1970. godine. (Gočin, Debeljak, 2016: 123.)

br. 561/2006 Europskog parlamenta i Vijeća o usklađivanju određenog socijalnog zakonodavstva koje se odnosi na cestovni promet (SL L 60, 28. 2. 2014.); u daljnjem tekstu: Uredba (EU) br. 165/2014. 
Zakon sadrži odredbe koje su u skladu sa sljedećim aktima Europske unije:

- Direktivom 2002/15 EZ Europskog parlamenta i Vijeća od 11. ožujka 2002. o organizaciji radnog vremena osoba koje obavljaju djelatnost mobilnog cestovnog prijevoza (SL L80, 23. 3. 2002.);

- Direktivom 2006/22/EZ Europskog parlamenta i Vijeća od 15. ožujka 2006. o minimalnim uvjetima za provedbu uredbi Vijeća (EEZ) br. 3820/85 i br. 3821/85 o socijalnim propisima vezanim uz djelatnost cestovnog prijevoza, te kojom se ukida Direktiva Vijeća 88/599/EEZ (SL L102, 11. 4. 2006.);

- Direktivom Komisije 2009/4/EZ od 23. siječnja 2009. o protumjerama za sprječavanje i otkrivanje neovlaštenog rukovanja zapisnicima tahografa te o izmjeni Direktive 2006/22/ EZ Europskog parlamenta i Vijeća o minimalnim uvjetima za provedbu uredbi Vijeća (EEZ) br. 3820/85 i (EEZ) br. 3821/85 o socijalnom zakonodavstvu koje se odnosi na djelatnosti cestovnog prijevoza i o stavljanju izvan snage Direktive Vijeća 88/599/EEZ (SL L 21/39, 24. 1. 2009.);

- Direktivom Komisije 2009/5/EZ od 30. siječnja 2009. o izmjeni Priloga III. Direktivi 2006/22/ EZ Europskog parlamenta i Vijeća o minimalnim uvjetima za provedbu uredbi Vijeća (EEZ) br. 3820/85 i (EEZ) br. 3821/85 o socijalnom zakonodavstvu koje se odnosi na aktivnosti cestovnog prometa (SL L 29/45, 31. 1. 2009.);

- Uredbom (EZ) br. 561/2006 Europskog parlamenta i Vijeća od 15. ožujka 2006. o usklađivanju određenog socijalnog zakonodavstva koje se odnosi na cestovni promet i o izmjeni uredbi Vijeća (EEZ) br. 3821/85 i (EZ) br. 2135/98 te o stavljanju izvan snage Uredbe Vijeća (EEZ) br. 3820/85 (SL L 102, 11. 4. 2006.);

- Uredbom (EU) br. 165/2014 Europskog parlamenta i Vijeća od 4. veljače 2014. o tahografima u cestovnom prometu, stavljanju izvan snage Uredbe Vijeća (EEZ) br. 3821/85 o tahografu u cestovnom prometu i izmjeni Uredbe (EZ) br. 561/2006 Europskog parlamenta i Vijeća o usklađivanju određenog socijalnog zakonodavstva koje se odnosi na cestovni promet (SL L60, 28. 2. 2014.);

- Uredbom Komisije (EU) br. 2016/403 od 18. ožujka 2016. o dopuni Uredbe (EZ) br. 1071/2009 Europskog parlamenta i Vijeća u pogledu klasifikacije teških povreda pravila Unije koje mogu dovesti do gubitka dobrog ugleda cestovnog prijevoznika te o izmjeni Priloga III Direktive 2006/22/EZ Europskog parlamenta i Vijeća (SL L 74/8, od 19. 3. 2016.);

- Uredbom Komisije (EU) br. 1266/2009 od 16. prosinca 2009. o desetoj prilagodbi tehničkom napretku Uredbe Vijeća (EEZ) br. 3821/85 o tahografu u cestovnom prometu (SL L 339/3, od 22. 12. 2009.) (čl. 2. Zakona o radnom vremenu, obveznim odmorima mobilnih radnika i uređajima za bilježenje u cestovnom prijevozu).

Sukladno njegovom članku 1., Zakonom o radnom vremenu, obveznim odmorima mobilnih radnika i uređajima za bilježenje $\mathrm{u}$ cestovnom prijevozu uređuje se radno vrijeme i obvezni odmori mobilnih radnika i vozača u cestovnom prijevozu, vremena vožnje, prekidi vožnje i dokumentacija, 
način, uvjeti i postupak stjecanja dozvole za radionice, memorijske kartice i uvjeti za njihovo izdavanje, postupci i provjere, službene evidencije, nadzor i inspekcija, odgovornost te prekršajne odredbe, a sve u cilju poboljšanja radnih i socijalnih uvjeta zaposlenika koji su obuhvaćeni ovim Zakonom, poboljšanja opće sigurnosti u cestovnom prometu te usklađivanja uvjeta tržišnog natjecanja između različitih vrsta kopnenog prometa, posebno u odnosu na cestovni promet, što proizlazi i iz određenja i ciljeva Uredbe (EZ) br. 561/2006 (Preambula Uredbe (EZ) br. 561/2006).

Zakon o radnom vremenu, obveznim odmorima mobilnih radnika i uređajima za bilježenje u cestovnom prijevozu primjenjuje se na mobilne radnike koji sudjeluju u aktivnostima cestovnog prijevoza, vozače, kao i na samozaposlene vozače vozila čija je najveća dopuštena masa veća od 3,5 tone, kao i na vozače vozila čija je najveća dopuštena masa s priključnim vozilom veća od 3,5 tona te na autobuse konstruirane ili trajno prilagođene za prijevoz više od devet putnika, uključujući vozača (čl. 3. Zakona o radnom vremenu, obveznim odmorima mobilnih radnika i uređajima za bilježenje u cestovnom prijevozu).

Sukladno navedenome, Zakon o radnom vremenu, obveznim odmorima mobilnih radnika i uređajima za bilježenje u cestovnom prijevozu primjenjuje se na sva vozila za prijevoz tereta čija ukupna masa prelazi 3,5 tone te na sva vozila kojima se prevozi više od 9 putnika, uključujući vozača.

Ipak, Zakon o radnom vremenu, obveznim odmorima mobilnih radnika i uređajima za bilježenje u cestovnom prijevozu pod određenim uvjetima predviđa i određena izuzeća pa tako u svojem članku 8. 'Izuzeća od tjednog radnog vremena i noćnog rada' u stavku 1. navodi da se iznimno od odredbi članka 5. i 7. koji se odnose na raspored radnog vremena i noćni rad, ${ }^{14} \mathrm{u}$ linijskom prijevozu putnika do 50 kilometara, ako za to postoji potreba iz objektivnih, tehničkih ili drugih razloga koji se odnose na organizaciju rada, na puno tjedno radno vrijeme i noćni rad mobilnih radnika mogu primjenjivati odredbe zakona kojime se uređuju radni odnosi ili kolektivni ugovor, pod uvjetom da postoji dogovor predstavnika poslodavaca i radnika.

Navedenu odredbu kroz svoje Mišljenje od 21. kolovoza 2017. godine dodatno tumači i resorno Ministarstvo mora, prometa i infrastrukture, u kojemu između ostalog naglašava da članak 8. stavak 1. propisuje moguće iznimke od primjene članka 5. i 7. „, i to uz zadovoljena dva bitna uvjeta: da se radi o linijskom prijevozu putnika do 50 kilometara i da postoji dogovor između predstavnika poslodavaca i radnika." (Ministarstvo mora, prometa i infrastrukture, 2017 b).

U tom smislu, iz propisanoga u Zakonu o radnom vremenu, obveznim odmorima mobilnih radnika i uređajima za bilježenje u cestovnom prijevozu proizlazi da se uz zakonom ispunjene okolnosti isti neće primjenjivati na vozače koji obavljaju linijski prijevoz putnika do 50 kilometara. Pri tome treba posebno obratiti pozornost na ispunjenje propisanih uvjeta, jer jedino u tom slučaju ova iznimka dolazi do primjene. Drugim riječima, određene odredbe

14 Navedenim je odredbama propisano tjedno radno vrijeme mobilnih radnika u trajanju od 48 sati. Ono se može produžiti do maksimalnih 60 sati tjedno, samo ako prosjek od 48 sati nije prekoračen unutar razdoblja od 4 mjeseca (čl. 5. st. 1. i 2. Zakona). Ako mobilni radnik obavlja poslove za različite poslodavce, radno vrijeme predstavlja zbroj radnih sati kod svih poslodavaca (čl. 5. st. 3. Zakona). Ako mobilni radnici obavljaju noćni rad, u tom im je razdoblju (od 00.00 do 05.00 sukladno čl. 4. st. 1. t. 5. ovog Zakona) ograničeno vrijeme ukupnog rada na najviše 10 sati unutar 24 sata (čl. 7. st. 1. Zakona). 
Zakona o radnom vremenu, obveznim odmorima mobilnih radnika i uređajima za bilježenje u cestovnom prometu neće se primjenjivati na vozače na linijskom prijevozu putnika do 50 kilometara samo u slučaju kada je na temelju dogovora predstavnika poslodavaca i radnika dogovorena primjena Zakona o radu ili kolektivnog ugovora. Koje će se norme primijeniti na ovu skupinu vozača ovisit će o tome postoje li takvi dogovori.

Odredba članka 8. stavka 1. govori o mogućoj primjeni „odredbi zakona kojime se uređuju radni odnosi", čime upućuje na Zakon o radu. Sukladno njegovom članku 1. tim se zakonom uređuju radni odnosi u Republici Hrvatskoj, ako drugim zakonom ili međunarodnim ugovorom, koji je sklopljen i potvrđen u skladu s Ustavom Republike Hrvatske, te objavljen, a koji je na snazi, nije drukčije određeno.

Za obradu i značaj ove teme taj poseban zakon je Zakon o radnom vremenu, obveznim odmorima mobilnih radnika i uređajima za bilježenje u cestovnom prijevozu, kao jedini mogući poseban zakon koji bi mogao drukčije uređivati radne odnose za vozače u cestovnom prometu roba i dobara. ${ }^{15} \mathrm{U}$ slučaju ispunjenja uvjeta iz članka 8. stavka 1., na vozače koji obavljaju linijski prijevoz putnika na udaljenosti do 50 kilometara moguće će se, ovisno o dogovoru, dakle primjenjivati odredbe Zakona o radu.

Ovdje se posebno treba usmjeriti i na već prikazanu odredbu članka 3. Uredbe (EZ) br. 561/2006 koja propisuje da se ista ne primjenjuje na cestovni prijevoz koji, između ostalih, obavljaju vozila koja se koriste za prijevoz putnika na linijskim vožnjama na udaljenosti do 50 kilometara. Prema navedenom određenju, ova su vozila izuzeta iz primjene Uredbe (EZ) br. 561/2006 i Uredba se na njih neće primjenjivati. Države članice bi trebale utvrditi pravila za vozila koja se koriste u prijevozu putnika na redovitim linijama na udaljenosti do $50 \mathrm{~km}$. Ta bi pravila trebala osigurati odgovarajuću zaštitu u vezi s dozvoljenim vremenom vožnje te obveznih razdoblja prekida vožnje i odmora (Preambula Uredbe (EZ) br. 561/2006).

Naš se zakonodavac nije upustio u posebnu regulaciju za vozila ove namjene te nemamo posebne odredbe kojima se uređuje dozvoljeno vrijeme vožnje, obvezna razdoblja prekida vožnje i odmora ovih vozača na linijskim vožnjama do 50 kilometara. ${ }^{16}$

15 Primjerice, može se spomenuti i posebnosti radnopravnog statusa radnika u pomorskom ribarstvu, koji kao i mobilni radnici, vozači, kroz relevantne pravne akte imaju poseban radnopravni položaj, koji na nacionalnoj ravni u prvom redu proizlazi iz odredbe članka 88. st. 1. Zakona o radu te odredbi Pravilnika o radnom vremenu, odmorima i dopustima radnika na pomorskim ribarskim plovilima, kao posebnog podzakonskog (provedbenog) akta, koji je stupio na snagu 16. siječnja 2016. godine. Naime, radni su odnosi radnika na pomorskim ribarskim plovilima, a na taj način posebno i ribara, posebna potkategorija specifičnih radnih odnosa u pomorstvu. Ti radni odnosi imaju svoje međunarodne heteronomne izvore (konvencije MOR-a, direktive EU-a), kao i posebne nacionalne heteronomne izvore, u prvom redu prethodno navedeni Pravilnik. Specifičnost je radnopravnog odnosa radnika na pomorskim ribarskim plovilima, uz ostalo, u registraciji ugovora, radnom vremenu i odmorima. (Učur, Smokvina, 2016). Ništa manje specifičan položaj nije ni onaj članova posade zrakoplova, čije se radno vrijeme i vrijeme leta, trajanje dežurstva i prijevoza, dužina dnevnog, tjednog i godišnjeg odmora i druga pitanja s time u svezi uređuju odredbama Zakona o zračnom prometu (NN br. 69/09., 84/11., 54/13., 127/13., 92/14.) i Pravilnika o radnom vremenu članova posade zrakoplova (NN br. 57/13., čl. 2. navedenog Pravilnika).

16 Ovdje treba obratiti pozornost na razliku između „radnog vremena“ i „vožnje“. Vožnja ulazi u „radno vrijeme“, odnosno u ono vrijeme tijekom kojega je mobilni radnik proveo na aktivnostima vožnje, utovara i istovara, pomoći putnicima pri ulasku i izlasku iz vozila, čišćenju i tehničkom održavanju vozila i drugima, sukladno čl. 4. st. 1. t. 8. Zakona, ali i definicijama iz čl. 4. Uredbe (EZ) br. 561/2006. 
Uredba (EZ) br. 561/2006 se na njih nesporno neće primjenjivati, a Zakon o radnom vremenu, obveznim odmorima mobilnih radnika i uređajima za bilježenje u cestovnom prometu svojim poljem primjene obuhvaća i ova vozila, u onom dijelu koji se odnosi na sva ona pitanja koja ulaze u sadržaj tog Zakona, odnosno na pitanja koja taj Zakon regulira.

Time, kada je riječ o dozvoljenom vremenu vožnje, obveznim razdobljima prekida vožnje i odmorima ovih vozača na linijama do 50 kilometara, a koja su pitanja u prvom redu uređena Uredbom (EZ) br. 561/2006, ${ }^{17}$ na ove se vozače ta pravila ne primjenjuju pa bi se na ove vozače neminovno primjenjivale i odredbe Zakona o radu, odnosno kolektivnih ili drugih ugovora između socijalnih partnera, koji za sada nisu sklopljeni.

Dozvoljeno vrijeme vožnje, razdoblja prekida vožnje i odmora vozača mogli bi se također urediti i povoljnije odredbama kolektivnih ili drugih ugovora između socijalnih partnera, kojima bi se moglo propisati povoljnije uvjete, jer tu mogućnost propisuje čl. 11. st. 2. Zakona o radnom vremenu, obveznim odmorima mobilnih radnika i uređajima za bilježenje u cestovnom prijevozu.

Na upit nadležnom Ministarstvu vezano upravo uz prijevoz putnika na linijskim vožnjama do 50 kilometara, Ministarstvo mora, prometa i infrastrukture naglašava kako „Uredba 561/2006 u odredbi članka 3. izuzima vozila koja se koriste za prijevoz putnika na linijskim vožnjama do 50 kilometara u pogledu dozvoljenih vremena vožnje, obveznih razdoblja prekida vožnje i odmora vozača. Zakon o radnom vremenu, obveznim odmorima mobilnih radnika i uređajima za bilježenje u cestovnom prijevozu (...) koji uređuje radno vrijeme i obvezni odmor mobilnih radnika i vozača u cestovnom prijevozu, vremena vožnje, prekide vožnje i ostalo, nije posebno uredio vremena vožnje, radno vrijeme, obvezne odmore i stanke vozača na linijskim vožnjama do 50 kilometara. Slijedom navedenog na vozače koji obavljaju prijevoz putnika na linijskim vožnjama do 50 kilometara u pogledu uređivanja radnih vremena, razdoblja odmora i stanki primjenjuju se odredbe kolektivnih ugovora, sporazuma između socijalnih partnera te odredbe zakona kojim se uređuju radni odnosi." (Ministarstvo mora prometa i infrastrukture, 2017 a)

Time nadležno Ministarstvo kod vozača koji obavljaju prijevoz putnika na linijskim vožnjama do 50 kilometara upućuje na odredbe kolektivnih ugovora, sporazuma između socijalnih partnera te odredbe zakona kojim se uređuju radni odnosi.

Jasno određenje, vezano uz naredni izuzetak, a uvedeno izmjenama i dopunama Zakona o radnom vremenu, obveznim odmorima mobilnih radnika i uređajima za bilježenje u cestovnom prijevozu ${ }^{18}$ nalazimo u članku 8. stavku 3. ovog Zakona kojim je propisano da se iznimke koje su propisane za prijevoz vozilima iz članka 13. stavka 1. Uredbe (EZ) br. 561/2006 primjenjuju u cijelosti.

17 Jer za razliku od istoimenog Zakona iz 2008. godine (NN br. 60/2008., 124/2010.) koji je novim Zakonom stavljen izvan snage, važeći Zakon ne sadrži detaljnije odredbe koje uređuju dozvoljeno vrijeme vožnje, obvezna razdoblja prekida vožnje i razdoblja odmora, na što se izravno primjenjuju odredbe Uredbe (EZ) br. 561/2006.

18 Članak 7. Zakona o izmjenama i dopunama Zakona o radnom vremenu, obveznim odmorima mobilnih radnika i uređajima za bilježenje u cestovnom prijevozu (NN br. 36/15.) 
U narednom stavku 4. članka 8. izričito se propisuje da se na vozače vozila koja su izuzeta u članku 13. stavku 1. Uredbe (EZ) br. 561/2006 primjenjuje zakon kojim se uređuju radni odnosi, dakle Zakon o radu, što je potpuno jasno određenje te iz navedenog u članku 8. stavku 4. jasno proizlazi da se na sve vozače koji upravljaju vozilima propisanim u članku 13. stavku 1. Uredbe (EZ) br. 561/2006 primjenjuje isključivo Zakon o radu.

Sljedeće pitanje koje se postavlja odnosi se na tahografe, pa će se u nastavku rada tematizirati nacionalni izvori prava koji se odnose na ugradnju uređaja za bilježenje radnog vremena i obveznih odmora mobilnih radnika - tahograf uređaja, jer su izravno povezani i s prethodno navedenim izuzećima, a posebno s vozačima na linijskim prijevozima putnika do 50 kilometara.

\subsection{Zakon o sigurnosti prometa na cestama}

Zakonom o sigurnosti prometa na cestama (NN 67/08., 48/10., 74/11., 80/13., 158/13., 92/14., 64/15., 108/17. $)^{19}$ utvrđuju se temeljna načela međusobnih odnosa, ponašanje sudionika i drugih subjekata u prometu na cesti, osnovni uvjeti kojima moraju udovoljavati ceste glede sigurnosti prometa, pravila prometa na cestama, sustav prometnih znakova i znakova koje daju ovlaštene osobe, dužnosti u slučaju prometne nesreće, osposobljavanje kandidata za vozače, polaganje vozačkog ispita i uvjeti za stjecanje prava na upravljanje vozilima, vuča vozila, uređaji i oprema koje moraju imati vozila, dimenzije, ukupna masa i osovinsko opterećenje vozila te uvjeti kojima moraju udovoljavati vozila u prometu na cestama (čl. 1. Zakona o sigurnosti prometa na cestama).

U pogledu dimenzija, ukupne mase i osovinskog opterećenja vozila, o uređajima i opremi koju moraju imati vozila i o uvjetima kojima moraju udovoljavati uređaji i oprema vozila u prometu na cestama, člankom 236. stavkom $2 .{ }^{20}$ Zakona o sigurnosti prometa na cestama ovlašćuje se ministra nadležnog za promet da u suglasnosti s ministrom nadležnim za unutarnje poslove donese propise o dimenzijama, ukupnoj masi i osovinskom opterećenju vozila, o uređajima i opremi koje moraju imati vozila i o uvjetima kojima moraju udovoljavati uređaji i oprema vozila u prometu na cestama (Pavišić, Matiša, 2012.; čl. 236. Zakona o sigurnosti prometa na cestama).

\subsection{Pravilnik o tehničkim uvjetima vozila u prometu na cestama}

Temeljem prethodno navedene odredbe Zakona o sigurnosti prometa na cestama donijet je Pravilnik o tehničkim uvjetima vozila u prometu na cestama (NN 85/16., 24/17.), ${ }^{21}$ u kojemu se u članku 77. stavku 1. upućuje na Uredbu (EU) br. 165/2014 te se navodi da vozila kategorije $\mathrm{Mi}$ $\mathrm{N}$ moraju biti opremljena tahografom u skladu s člankom 3. Uredbe (EU) br. 165/2014. Prema navedenoj Uredbi tahograf uređaji ugrađuju se i koriste u vozilima registriranim u državi članici koja služe za cestovni prijevoz putnika ili dobara i na koje se primjenjuje Uredba (EZ) br. 561/2006. (čl. 3. st. 1. Uredbe (EU) br. 165/2014).

19 U daljnjem tekstu: Zakon o sigurnosti prometa na cestama.

20 Do najnovijih izmjena i dopuna Zakona o sigurnosti prometa na cestama iz 2017. godine radilo se o stavku 4. navedenog članka (čl. 25. Zakona o izmjenama i dopunama Zakona o sigurnosti prometa na cestama, NN br. 108/07.).

21 U daljnjem tekstu: Pravilnik o tehničkim uvjetima vozila u prometu na cestama. 
Već je navedeno kako se Uredba (EZ) br. 561/2006 primjenjuje na cestovni prijevoz tereta gdje najveća dopuštena masa vozila, uključujući prikolicu ili poluprikolicu, prelazi 3,5 tona ili na cestovni prijevoz putnika vozilima koja su konstruirana ili trajno prilagođena za prijevoz više od devet osoba uključujući vozača te su namijenjena za tu svrhu (čl. 2. st. 1. Uredbe (EZ) br. 561/2006).

Ista Uredba kroz članak 3. navodi da se ne primjenjuje na cestovni prijevoz koji obavljaju vozila koja se koriste za prijevoz putnika na linijskim vožnjama na udaljenosti do 50 kilometara, vozila čija najveća dopuštena brzina ne prelazi četrdeset kilometara na sat, vozila koja su u vlasništvu ili u najmu oružanih snaga, civilne zaštite, vatrogasnih službi ili snaga za održavanje javnog reda, bez vozača, ako je prijevoz koji se obavlja vezan uz zadaće koje su dodijeljene tim službama te se obavljaju pod njihovom kontrolom, specijalizirana vozila koja se koriste $u$ medicinske svrhe i druga, sukladno već prethodno navedenome $u$ ovom radu.

Prema određenju Pravilnika o tehničkim uvjetima vozila u prometu na cestama, tahografi se moraju ugraditi u sva vozila M i N kategorije u skladu s člankom 3. Uredbe (EU) br. 165/2014, a budući da je iz odredbi Uredbe (EZ) br. 561/2006 jasno vidljivo da se ona ne primjenjuje na vozila iz članka 3. te Uredbe, nedvojbeno proizlazi da ta vozila ne moraju imati ugrađen tahograf uređaj. Navedeno naglašava i Ministarstvo mora, prometa i infrastrukture u mišljenju od 18. svibnja 2017. godine kroz sljedeće očitovanje: „(...) Sukladno odredbi članka 3. Uredbe 165/2014, vozila koja obavljaju prijevoz na koji se ne primjenjuje Uredba 561/2006 ne moraju imati ugrađen tahograf i voditi evidenciju putem tahografa.(...)“ (Ministarstvo mora, prometa i infrastrukture, 2017 a)

Posljedično, Centar za vozila Hrvatske d. d., referirajući se na odredbe navedenog Pravilnika i Uredbe (EZ) br. 561/2006 te navedeno Mišljenje resornog Ministarstva iz svibnja 2017. godine, upućuje dopis od 30. kolovoza 2017. godine svim stanicama za redoviti, odnosno preventivni tehnički pregled vozila u Republici Hrvatskoj u kojemu navodi sljedeće: „(...) vozila koja se koriste za prijevoz putnika na linijskim vožnjama na udaljenosti do 50 kilometara ne moraju biti opremljena tahografom. To znači da se na tehničkom pregledu ne treba zahtijevati da gradski autobusi budu opremljeni tahografom, odnosno, ako su opremljena tahografom, on ne mora imati važeće ispitivanje." (Centar za vozila Hrvatske, 2017)

\section{PRIMJENA IZUZEĆA ZA VOZAČE, ODNOSNO VOZAČE I VOZILA}

U cilju što jasnije predodžbe o tome koja su vozila obuhvaćena kojim izuzetcima, u ovom poglavlju bit će obrađene sve dosada navedene izuzete kategorije vozila, ali u dva djela, s obzirom na to da je s jedne strane riječ o vozilima čiji su vozači izuzeti od obveze vođenja evidencije putem tahografa te se na njih ne primjenjuje Zakon o radnom vremenu, obveznim odmorima mobilnih radnika i uređajima za bilježenje u cestovnom prijevozu, a i ta vozila su izuzeta od obveze ugradnje tahograf uređaja, dok je s druge strane riječ o još uvijek postojećoj skupini vozila čiji su vozači izuzeti iz obveze vođenja evidencije putem tahograf uređaja te se na njih ne primjenjuje Zakon o radnom vremenu, obveznim odmorima mobilnih radnika i uređajima za bilježenje u cestovnom prijevozu, ali ta ista 
vozila nisu izuzeta od obveze ugradnje tahograf uređaja.

\section{1 Izuzeće za vozače i vozila}

Iz do sada obrađenog teksta vidljivo je da je Uredba (EZ) br. 561/2006. iz svoje primjene isključila vozila koja se koriste za prijevoz putnika na linijskim vožnjama na udaljenosti do 50 kilometara. Zakon o radnom vremenu, obveznim odmorima mobilnih radnika i uređajima za bilježenje u cestovnom prijevozu nije posebno uredio dozvoljeno vrijeme vožnje, obvezna razdoblja prekida vožnje i odmore vozača koji upravljaju vozilima za linijski prijevoz putnika na udaljenostima do 50 kilometra te je Uredbom (EZ) br. 561/2006 jasno navedeno da se ona ne primjenjuje na vozila kojima se obavlja linijski prijevoz putnika do 50 kilometara u pogledu obveze ugradnje tahograf uređaja. Iz odredbi Pravilnika o tehničkim uvjetima vozila u prometu na cestama, s obzirom na određenja Uredbe (EU) br. 165/2014 te polje primjene Uredbe (EZ) br. 561/2006. proizlazi da određene kategorije vozila, između ostalih i ona koja se koriste za prijevoz putnika na linijskim vožnjama na udaljenosti do 50 kilometara nisu obuhvaćene dometom obveze ugradnje i korištenja tahografa. Samim time i vozači tih vozila izuzeti su od obveze vođenja evidencije radnog vremena putem tahograf uređaja.

\subsection{Izuzeće za vozače}

Kao što je prethodno u ovom radu prikazano, Zakonom o radnom vremenu, obveznim odmorima mobilnih radnika i uređajima za bilježenje u cestovnom prijevozu kroz članak 8. stavak 3 . izuzeti su vozači određenih kategorija vozila, kao što su vozila koja su u vlasništvu ili su ih iznajmila, bez vozača, tijela javne vlasti za obavljanje cestovnog prijevoza koji ne predstavlja konkurenciju privatnim prijevoznicima, vozila koja koriste ili su ih iznajmila, bez vozača, poljoprivredna, hortikulturna, šumarska, stočarska ili ribarska poduzeća za prijevoz tereta za potrebe svoje vlastite poduzetničke djelatnosti u krugu do $100 \mathrm{~km}$ od sjedišta poduzeća, vozači poljoprivrednih i šumarskih vozila za vuču koja se koriste za poljoprivredne ili šumarske djelatnosti, u krugu do $100 \mathrm{~km}$ od sjedišta poduzeća koje vozilo ima u vlasništvu, najmu ili zakupu, i druga, sukladno navedenom članku. Vozači navedenih vozila izuzeti su od obveze vođenja evidencije radnog vremena putem tahograf uređaja, no ista ta vozila kojima oni upravljaju nisu izuzeta od obveze ugradnje i kontrole tahograf uređaja.

\section{RADNO VRIJEME, OBVEZNI ODMORI I EVIDENCIJA O RADNOM VREMENU IZUZETIH VOZAČA}

Pitanje regulacije radnog vremena jedno je od najstarijih u povijesti radnog prava. O tome svjedoči uspostavljena regulativa, kako na međunarodnoj, tako i na nacionalnoj razini, s ciljem skraćivanja radnog vremena radi zaštite sigurnosti i zdravlja radnika. $S$ druge strane, osamdesetih godina prošlog stoljeća započela je fleksibilizacija i diverzifikacija radnog vremena, s ciljem povećanja produktivnosti i kompetitivnosti poslodavca te stope zaposlenosti (Bilić, 2017). Supranacionalno europsko zakonodavstvo nastoji utvrditi minimalne standarde radnoga vremena kako bi nacionalna 
gospodarstva, ali i pojedini gospodarski subjekti "imali iste startne osnove" u pogledu uvjeta rada, pa tako i uvjeta tržišnoga natjecanja, prema usporedivim osnovama i pravnoj regulativi (BodirogaVukobrat, Laleta, Jukić, 2008). Posebno pitanje predstavljanju novi oblici fleksibilnog zapošljavanja koje obilježava snažna ili prevladavajuća podrška informacijske i komunikacijske tehnologije, a koji se javljaju i u djelatnosti pružanja usluga prijevoza putnika (Bjelinski Radić, 2017).

Ova danas iznimno aktualna pitanja, značajna su naravno i za mobilne radnike, vozače, prvenstveno u pogledu sigurnosti i zaštite zdravlja ovih radnika, ali jednako tako i putnika i ostalih sudionika u cestovnom prometu.

Za vozače na koje se ne primjenjuju specifične odredbe o radnom vremenu, obveznim odmorima mobilnih radnika i uređajima za bilježenje u cestovnom prijevozu njihovo radno vrijeme, obvezni odmori, kao i druga pitanja s tim u vezi uređuju se temeljem zakona kojim se uređuju radni odnosi u Republici Hrvatskoj, a temeljni izvor prava u tom pogledu je Zakon o radu, koji sveobuhvatno regulira ova pitanja, o čemu je već bilo riječi prethodno u radu.

Dakle, izuzeti vozači se zbog specifičnosti njihova rada „vraćaju“ u zakonodavno okrilje Zakona o radu, koje ova pitanja regulira za veliku većinu različitih kategorija zaposlenika, dok se kod „neizuzetih“ vozača primjenjuju odredbe posebnog propisa, odnosno Zakona o radnom vremenu, obveznim odmorima mobilnih radnika i uređajima za bilježenje u cestovnom prometu. Ovaj poseban propis, uključujući ovdje naravno i izravno primjenjiva određenja iz pravih izvora EU-a, na specifičan način regulira njihovo radno vrijeme, obvezne odmore i način na koji su o tome dužni voditi odgovarajuću evidenciju (Gočin, Debeljak, 2016), o čemu se govorilo u radu na pojedinim mjestima.

\section{1 Radno vrijeme}

Zakonom o radu propisano je što predstavlja radno vrijeme, najdulje radno vrijeme, nepotpuno radno vrijeme, skraćeno radno vrijeme, prekovremeni rad, raspored radnog vremena, preraspodjela radnog vremena, uvjeti noćnog i smjenskog rada, odmori i dopusti, izuzeci od primjene nekih odredbi o radnom vremenu i odmorima, mogućnost samostalnog određivanja radnog vremena. Radno vrijeme ugovorit će se ugovorom o radu, a može se odrediti i kolektivnim ugovorom te pravilnikom o radu (Rožman, 2016 b).

Ako je reguliranje radnog vremena određeno autonomnim izvorom prava - pravilnikom o radu, kolektivnim ugovorom i slično, isti moraju biti u skladu sa Zakonom o radu, točnije autonomni izvori prava mogu se dogovarati, propisivati i primjenjivati na način da budu povoljniji za radnika od propisanog Zakonom o radu.

Radno vrijeme prema Zakonu o radu može biti puno, nepuno i skraćeno radno vrijeme. Vrsta radnog vremena definira se ugovorom o radu koji sklapaju i potpisuju poslodavac i radnik.

Pojam radnog vremena definiran je člankom 60. Zakona o radu te u stavcima od 1. do 4. navodi sljedeće: 
(1) Radno vrijeme je vrijeme u kojem je radnik obavezan obavljati poslove, odnosno $u$ kojem je spreman (raspoloživ) obavljati poslove prema uputama poslodavca, na mjestu gdje se njegovi poslovi obavljaju ili drugom mjestu koje odredi poslodavac.

(2) Radnim vremenom ne smatra se vrijeme u kojem je radnik pripravan odazvati se pozivu poslodavca za obavljanje poslova ako se pokaže takva potreba, pri čemu se radnik ne nalazi na radnom mjestu na kojem se njegovi poslovi obavljaju niti na drugom mjestu koje je odredio poslodavac.

(3) Vrijeme pripravnosti i visina naknade uređuje se ugovorom o radu ili kolektivnim ugovorom.

(4) Vrijeme koje radnik provede obavljajući poslove po pozivu poslodavca smatra se radnim vremenom, neovisno o tome obavlja li ih u mjestu koje je odredio poslodavac ili u mjestu koje je odabrao radnik.

Zakon o radu propisao je da puno radno vrijeme radnika ne može biti dulje od 40 sati tjedno (čl. 61. st. 1.Zakona o radu). Ono ustvari predstavlja najdulje radno vrijeme koje radnik i poslodavac mogu ugovoriti, ali radnik može tijekom tjedna raditi dulje zbog prekovremenog rada, preraspodjele radnog vremena, nejednakog rasporeda radnog vremena, što ne utječe na ograničenje $u$ mogućnosti ugovaranja punog radnog vremena (Rožman, 2016 b).

\section{2 Raspored radnog vremena}

Raspored radnog vremena propisan je člankom 66. Zakona o radu, stavcima 1. do 15. Radno vrijeme radnika može se rasporediti u jednakom, odnosno nejednakom trajanju po danima, tjednima, odnosno mjesecima, u kojem slučaju tijekom jednog razdoblja može trajati duže, a tijekom drugog razdoblja može trajati kraće od punog, odnosno nepunog radnog vremena. Pri tome je radi zaštite radnika kojem je radno vrijeme nejednako raspoređeno po tjednima, ovakav rad ograničen na dva načina - $u$ odnosu na ukupno trajanje rada u tjednu i to na 50 sati rada u tjednu te u odnosu na ukupan fond sati koji radnik može odraditi u vremenskom razdoblju od uzastopna četiri mjeseca i to na prosječno 48 sati tjedno. Ujedno se ostavlja mogućnost da se fond sati rada u tjednu s 50 sati poveća na 60 sati, i više, ali to samo kroz kolektivni ugovor, čime se osigurava nadzor sindikata kao stranke kolektivnog ugovora. Također se omogućava kolektivnim ugovorom produžiti referentno razdoblje u kojem se radi dulje na šest mjeseci.

Poslodavac je dužan obavijestiti radnika o njegovu rasporedu ili promjeni njegova rasporeda rada najmanje tjedan dana unaprijed, osim u slučaju prijeke potrebe za radom radnika. Posebno je važno naglasiti da je poslodavac dužan obavijestiti radnike o uvođenju nejednakog rasporeda te uvjetima tog rasporeda. Poslodavac se ne bi mogao naknadno pozvati na nejednaki raspored $\mathrm{i}$ odbiti radnicima platiti prekovremeni rad, pozivom na nejednaki raspored o kojem radnike nije obavijestio (Rožman, 2016 b). 


\section{3 Odmori}

\section{3. 1 Stanka u tijeku rada}

Radnik ima pravo na stanku tijekom rada od najmanje 30 minuta ako radi barem šest sati rada dnevno. Stanka se računa u radno vrijeme. Maloljetni radnici stječu pravo na stanku ako rade najmanje četiri i pol sata dnevno. Radnik koji radi najmanje šest sati kod dva ili više poslodavaca imat će kod svakog pravo na stanku razmjerno vremenu rada. Ako, primjerice, radnik radi pet sati kod jednog poslodavca, a jedan sat kod drugoga, kod prvog će imati pravo na stanku od 25 minuta, a kod drugog na stanku od pet minuta. Pod jednakim uvjetima pravo na stanku imat će maloljetni radnik koji u nepunom radnom vremenu radi kod dva ili više poslodavaca ukupno dnevno više od četiri i pol sata. Ako posebna narav posla ne omogućuje prekid rada radi korištenja stanke, vrijeme i način njenog korištenja riješit će se kolektivnim ugovorom, sporazumom sklopljenim između radničkog vijeća i poslodavca ili ugovorom o radu. (Rožman, 2016 b; čl. 73. Zakona o radu).

\section{3.2 Dnevni odmor}

Radnik ima pravo na odmor od 12 sati neprekidno tijekom svakih 24 sata (čl. 74. st. 1. Zakona o radu). Svrha određivanja prava radnika na odmor je sprječavanje odnosno ublažavanje umora radnika, obnavljanja njegove radne snage, a samim time i očuvanje zdravlja i sigurnosti na radu (Rožman, 2016 b).

\subsubsection{Tjedni odmor}

Radnik ima pravo na tjedni odmor u neprekidnom trajanju od najmanje dvadeset četiri sata, kojem se pribraja dnevni odmor iz članka 74. Zakona o radu (čl. 75. st. 1. Zakona o radu). Maloljetni radnici imaju pravo na tjedni odmor u neprekidnom trajanju od najmanje četrdeset osam sati (čl. 75. st. 2. Zakona o radu). Tjedni odmor radnik koristi nedjeljom, te u dan koji nedjelji prethodi, odnosno iza nje slijedi (čl. 75. st. 3. Zakona o radu).

Ako radnik ne može koristiti odmor u propisanom trajanju mora mu se za svaki radni tjedan omogućiti korištenje zamjenskog tjednog odmora po okončanju razdoblja koje je proveo na radu, zbog kojeg tjedni odmor nije koristio ili ga je koristio u kraćem trajanju (čl. 75. st. 4. Zakona o radu).

Iznimno, radnicima koji zbog obavljanja poslova u različitim smjenama ili objektivno nužnih tehničkih razloga ili zbog organizacije rada ne mogu iskoristiti odmor od najmanje 24 sata kojem se pribraja dnevni odmor, pravo na tjedni odmor može biti određeno u neprekidnom trajanju od najmanje dvadeset četiri sata, kojem se ne pribraja dnevni odmor iz članka 74. Zakona o radu (čl. 75. st. 5. Zakon o radu).

Iz prethodno prikazanih zakonskih odredbi o tjednom odmoru vidljivo je da je Zakonom o radu propisano da tjedni odmor radnik koristi nedjeljom, odnosno ako ga ne može koristiti nedjeljom, onda u dan koji nedjelji prethodi odnosno iza nje slijedi. To bi značilo da je poslodavac dužan radnicima koji ne mogu tjedni odmor koristiti nedjeljom, omogućiti tjedni odmor u subotu ili u ponedjeljak. No ova odredba u praksi ima vrlo ograničen doseg, jer kada se radi o djelatnostima koje 
se neprekidno obavljaju (prijevoz, zdravstvo, socijalna skrb i sl.) nemoguće je organizirati raspored da svi imaju tjedni odmor ili u nedjelju ili u subotu odnosno ponedjeljak, pa se ova odredba više primjenjuje u svezi stavka 4., tj. kao zamjenski tjedni odmor (Rožman, 2016 b).

\section{4 Evidencija radnog vremena izuzetih vozača}

Poslodavac je dužan voditi evidenciju o radnicima koji su kod njega zaposleni. Navedena evidencija mora sadržavati podatke o radnicima i radnom vremenu, a te je podatke poslodavac dužan dostaviti inspektoru rada na njegov zahtjev. Ministar nadležan za rad pravilnikom propisuje sadržaj i način vođenja ove evidencije (čl. 5. st. 1.-4. Zakona o radu).

Pravilnikom o sadržaju i načinu vođenja evidencije o radnicima (NN br. $73 / 17.)^{22}$ propisuje se sadržaj i način vođenja evidencije o radnicima, ako drugim propisom nije drukčije uređeno (čl. 1. st. 1.), što znači da se na mobilne radnike - vozače na koje se primjenjuju odredbe o radnom vremenu, obveznim odmorima mobilnih radnika i uređajima za bilježenje $u$ cestovnom prijevozu primjenjuje način vođenja evidencije o radnom vremenu i radnicima propisan odredbama Zakona o radnom vremenu, obveznim odmorima mobilnih radnika $i$ uređajima za bilježenje u cestovnom prijevozu.

Na radnike - vozače izuzete iz odredbi o radnom vremenu, obveznim odmorima mobilnih radnika i uređajima za bilježenje u cestovnom prijevozu u pogledu evidencije o radnicima i radnom vremenu primjenjuju se odredbe navedenog Pravilnika o sadržaju i načinu vođenja evidencije o radnicima kojim je propisano da je potrebno voditi evidenciju o radnicima $\mathrm{i}$ evidenciju o radnom vremenu.

Evidencija o radnicima sadrži najmanje podatke propisane u članku 3. stavku 1. ovog Pravilnika, kao što je ime i prezime radnika, njegov OIB, spol, dan, mjesec i godina rođenja, državljanstvo, prebivalište, odnosno boravište, stručno obrazovanje, datum početka rada, mjesto rada, odnosno napomenu da se rad obavlja na različitim mjestima, ugovoreno tjedno radno vrijeme, određeno puno radno vrijeme, odnosno propisano skraćeno radno vrijeme u satima, datum i razlog prestanka radnog odnosa i druge.

Poslodavac je dužan voditi i podatke o kojima ovisi ostvarenje pojedinih prava iz radnog odnosa ili u vezi s radnim odnosom, kao što je mirovinski staž do početka rada kod poslodavca, profesionalna bolest, ozljeda na radu, profesionalna nesposobnost za rad, invalidnost i druge (čl. 3. st. 2. Pravilnika o sadržaju i načinu vođenja evidencije o radnicima).

Evidencija o radnom vremenu sadrži najmanje podatke o imenu i prezimenu radnika, datumu u mjesecu, početku rada, završetku rada, vremenu i satima zastoja, prekidu rada i slično do kojega je došlo krivnjom poslodavca ili zbog drugih okolnosti za koje radnik nije odgovoran, nadalje podatke o ukupnom dnevnom radnom vremenu, satima terenskog rada, satima pripravnosti te vremenu nenazočnosti na radu. Podaci o vremenu nenazočnosti na radu

22 U daljnjem tekstu Pravilnik o sadržaju i načinu vođenja evidencije o radnicima. 
obuhvaćaju sate korištenja odmora (dnevnog, tjednog i godišnjeg), neradne dane i blagdane utvrđene posebnim propisom, sate spriječenosti za rad zbog privremene nesposobnosti za rad, sate plaćenih dopusta, sate nenazočnosti u tijeku dnevnog rasporeda radnog vremena po zahtjevu radnika, odnosno one u kojima radnik svojom krivnjom ne obavlja ugovorene poslove, sate provedene u štrajku te sate isključenja s rada (engl. lockout) (čl. 8. st. 1. Pravilnika o sadržaju i načinu vođenja evidencije o radnicima).

Osim prethodno navedenih podataka, poslodavac je dužan voditi i posebne podatke o radnom vremenu od kojih ovisi ostvarenje pojedinih prava iz radnog odnosa ili u vezi s radnim odnosom (sate rada noću, prekovremeni rad, smjenski rad, dvokratni rad, rad u dane blagdana ili neradnih dana utvrđenih posebnim propisom i druge) (čl. 8. st. 2. Pravilnika o sadržaju i načinu vođenja evidencije o radnicima).

Podatke o početku i završetku rada poslodavac je obvezan voditi samo ako je obveza vođenja tih podataka ugovorena kolektivnim ugovorom, sporazumom sklopljenim između radničkog vijeća i poslodavca, ugovorom o radu ili je uređena pravilnikom o radu (čl. 8. st. 3. Pravilnika o sadržaju i načinu vođenja evidencije o radnicima).

Poslodavac koji vodi, odnosno koji je obvezan voditi podatke o početku i završetku rada, u evidenciji radnog vremena nije dužan evidentirati podatak o satima korištenja dnevnog $i$ tjednog odmora (čl. 8. st. 4. Pravilnika o sadržaju i načinu vođenja evidencije o radnicima).

Za radnike kojima je radno vrijeme raspoređeno $\mathrm{u}$ jednakom trajanju $\mathrm{i}$ jednakom rasporedu po danima, tjednima i mjesecima, poslodavac nije dužan u evidenciji radnog vremena evidentirati podatak o satima korištenja dnevnog i tjednog odmora (čl. 8. st. 5. Pravilnika o sadržaju i načinu vođenja evidencije o radnicima).

Poslodavac je dužan u evidenciji radnog vremena voditi samo dosad navedene podatke koji su ostvareni u razdoblju, odnosno mjesecu za koje se plaća ili naknada plaće isplaćuje (čl. 8. st. 6. Pravilnika o sadržaju i načinu vođenja evidencije o radnicima).

Evidenciju o radnom vremenu poslodavac je obvezan voditi i za radnike koje mu je ustupila agencija za privremeno zapošljavanje, ako je ugovorom o ustupanju radnika preuzeo tu obvezu (čl. 8. st. 7. Pravilnika o sadržaju i načinu vođenja evidencije o radnicima).

Podaci o radnom vremenu mogu se voditi u pisanom ili u elektroničkom obliku. Prilikom vođenja evidencije moguće je koristiti odgovarajuće kratice, ali uz odgovarajuće nedvojbeno i jasno pojašnjenje značenja svake kratice. $U$ tome smislu na početku dokumenta na kojem se vodi evidencija trebalo bi biti navedeno što znači pojedina kratica (Rožman, 2016 a.; čl. 14. st. 1. Pravilnika o sadržaju i načinu vođenja evidencije o radnicima).

Evidenciju o radnom vremenu poslodavac je dužan čuvati najmanje šest godina, a u slučaju kada ima saznanja da je pokrenut radni spor u pogledu ostvarenja prava iz radnog odnosa ili u svezi s radnim odnosom, pri čemu bi za ostvarivanje tih prava mogle biti relevantne i evidencije, iste je dužan čuvati do pravomoćnog okončanja tog spora. Radnik ima pravo uvida u evidencije (čl. 14. st. 2. i 3. Pravilnika o sadržaju i načinu vođenja evidencije o radnicima). 
Naravno, iako takvo što nije propisano, radnik bi imao pravo prigovora evidenciji i tražiti da se podaci isprave (Rožman, $2016 \mathrm{a}$ ).

\section{PREDNOSTI I NEDOSTACI PRIMJENE IZUZEĆA}

S obzirom na to da se izuzeća primjenjuju na vozače određenih vozila, kao i na određena vozila kojim se obavlja određeni prijevoz, a koja su djelomično ili u potpunosti izuzeta iz obveze ugradnje i korištenja tahograf uređaja, ovo poglavlje obrađeno je kroz dvije zainteresirane strane, točnije u pogledu prednosti i nedostataka vezanih uz vozače, te poslodavce.

\section{1 Prednosti i nedostaci za vozače}

Prednosti se svakako očituju u tome što vozači koji su izuzeti primjene specifičnih odredbi o radnom vremenu, dozvoljenom vremenu vožnje, obveznim odmorima te uređajima za bilježenje u cestovnom prometu imaju manju količinu izvora prava u pogledu uređenja radnog odnosa i uređenja radnog vremena, organizacije rada i obveznih odmora.

Jednako tako sami vozači imaju manje obveza prilikom obavljanja svakodnevnih poslova, jer nisu obvezni koristiti tahograf uređaje, točnije nisu obvezni ispisivati tahograf listiće ili koristiti memorijske kartice vozača.

Samim time što nisu obvezni koristiti memorijske kartice vozača, oslobođeni su od troška koji bi imali za ishođenje memorijske kartice vozača. Vezano za medij na kojem se vodi evidencija radnog vremena i obveznih odmora mobilnih radnika - vozača, potrebno je napomenuti da se prednost očituje u svakom slučaju u pogledu diskriminacije samih vozača, jer oni vozači koji vode evidenciju putem tahograf listića, točnije vozači koji upravljaju vozilima u koja su ugrađeni analogni tahografi imaju od strane poslodavca osigurane tahograf listiće koje svakodnevno koriste, dok vozači koji upravljaju vozilima koja su opremljena digitalnim tahografima koriste memorijske kartice vozača koje su dužni osobno pribaviti i o vlastitom trošku. Samim time pojavljuje se diskriminacija između vozača na koje se primjenjuje Zakon o radnom vremenu, obveznim odmorima mobilnih radnika i uređajima za bilježenje u cestovnom prijevozu s obzirom da on navodi da je kartica vozača vlasništvo vozača koji sam snosi troškove njezina izdavanja (čl. 19. st. 4. Zakona o radnom vremenu, obveznim odmorima mobilnih radnika i uređajima za bilježenje u cestovnom prijevozu).

U praksi se može konstatirati da su određeni poslodavci - prijevoznici izračunali da jedan vozač godišnje koristi više od 300 tahograf listića, s obzirom na to da koristi godišnji odmor i eventualno neke druge slobodne dana za koje je evidenciju nadomjestio potvrdom o aktivnosti vozača, što bi značilo da u periodu od 5 godina, koliko je valjanost memorijske kartice vozača isti potroši 1500 komada tahograf listića, točnije, poslodavac ima trošak koji je sigurno veći od troška izdavanja memorijske kartice vozača, te se nerijetko poslodavac odlučuje vozačima namiriti trošak izdavanja memorijske kartice vozača. Obzirom da postoji mogućnost da će vozač nakon određenog vremena napustiti poslodavca te otići kod drugog poslodavca, gdje bi eventualno mogao raditi s memorijskom karticom vozača koju je platio prethodni poslodavac, u većini slučajeva poslodavac i radnik sklapaju sporazum kako će radnik koji eventualno napusti poslodavca u periodu za koji je 
izdana memorijska kartica vozača poslodavcu namiriti razmjerni dio troška izdavanja memorijske kartice vozača.

Potrebno je svakako navesti činjenicu da su vozači koji su izuzeti iz obveze vođenja evidencije o radnom vremenu i obveznim odmorima mobilnih radnika putem uređaja za bilježenje u cestovnom prijevozu oslobođeni od obveze pristupanja očitanju memorijskih kartica, najkasnije svakih dvadeset i jedan dan ili predaje tahograf listića starijih od dvadeset i osam dana.

Posebna prednost očituje se u tome što vozači koji su izuzeti od primjene Zakona o radnom vremenu, obveznim odmorima mobilnih radnika i uređajima za bilježenje u cestovnom prijevozu ne podliježu prekršajnim odredbama koje su propisane istim zakonom, a odnose se na poštovanje dozvoljenog vremena vožnje, obveznih stanki i odmora, kao i samog načina vođenja evidencije.

Ovdje je potrebno posebno napomenuti da to ne znači da isti ti vozači mogu činiti prekršaje te biti eventualna opasnost u cestovnom prometu, jer su dužni poštovati sve prometne propise i pravila koji vrijede u cestovnom prijevozu. Ovi vozači oslobođeni su od prekršaja koji su vezani uz dozvoljeno vrijeme vožnje, obvezne stanke i odmore te način vođenja evidencije. $U$ tom pogledu bitno je istaknuti da su izuzetcima uglavnom oslobođeni vozači koji svakodnevne poslove obavljaju u mjestu stanovanja, te da isti koriste obvezne odmore od najmanje 12 sati svakoga dana te stanke unutar radnog vremena u najmanjem trajanju od 30 minuta, ako rade najmanje šest sati dnevno, tako da u pogledu odmorenosti izuzetih vozača možemo govoriti samo o tome da je angažiranost istih omogućena u daleko manjem vremenu nego što je ono dozvoljeno za vozače na koje se primjenjuju posebne odredbe o radnom vremenu, obveznim odmorima mobilnih radnika i uređajima za bilježenje u cestovnom prijevozu.

U pogledu eventualnih nedostataka za vozače koji su izuzeti iz primjene posebnih odredbi o radnom vremenu, obveznim odmorima mobilnih radnika i uređajima za bilježenje u cestovnom prijevozu, a samim time i vođenja evidencije radnog vremena putem uređaja za bilježenje u cestovnom prijevozu, potrebno je istaknuti da nema evidentnih nedostataka, niti u kojem pogledu.

\subsection{Prednosti i nedostaci za poslodavce}

Prednosti za vlasnike vozila koja su izuzeta iz obveze ugradnje tahograf uređaja i čiji su vozači oslobođeni primjene odredbi o radnom vremenu, obveznim odmorima mobilnih radnika $i$ uređajima za bilježenje u cestovnom prijevozu, prije svega očituju se u smanjenju troškova poslovanja koji proizlaze iz toga što vlasnik vozila, odnosno poslodavac nije u obvezi u tom vozilu imati ugrađen tahograf uređaj. To je smanjenje troškova prilikom same nabavke vozila, a samim time ne postoji rizik od eventualnih kvarova na tahograf uređaju. Prilikom registracije vozila, ili produženja registracije, oslobođen je od troška ispitivanja - baždarenja tahografa koje se provodi svake dvije godine.

Nadalje prednost se očituje u tome što poslodavac nema svakodnevni trošak u obliku potrošnje tahograf listića, ako bi u vozilima imao ugrađen analogni tahograf.

Prednost se očituje i u tome što u slučaju izuzeća poslodavac nije u obvezi prikupljanja i obrade podataka iz tahograf listića ili memorijskih kartica vozača, što u svakom slučaju smanjuje troškove 
dodatno angažiranih radnika na poslovima prikupljanja i obrade podataka, odnosno troškova vanjskog poslovnog subjekta ako se odlučio da će obradu podataka povjeriti nekome drugom.

Jednako tako prednost se očituje u tome što poslodavac nije u obvezi čuvanja ovakve evidencije u najmanjem trajanju od tri godine.

Posebna prednost za poslodavce očituje se u tome što svi oni koji su izuzeti od primjene odredbi o radnom vremenu, obveznim odmorima za mobilne radnike i uređajima za bilježenje u cestovnom prijevozu nemaju rizik od eventualnih prekršaja koji su propisani tim odredbama te su samim time u prednosti i pravna osoba i odgovorna osoba u toj pravnoj osobi.

Nedostaci vezani uz izuzeće vozača od primjene pravila o radnom vremenu, obveznim odmorima mobilnih radnika i uređajima za bilježenje u cestovnom prijevozu mogla bi se očitovati u tome što poslodavac nije u mogućnosti koristiti svoje vozače duže od propisanog Zakonom o radu ili nekim drugim propisom koji mora biti u skladu sa Zakonom o radu koji je propisao da je puno tjedno radno vrijeme četrdeset sati, te obavljati nadzor nad radom svojih vozača putem tahograf uređaja. Međutim iz prakse se može zaključiti da poslodavci gotovo i ne koriste tahograf uređaje u svrhu praćenja aktivnosti vozača, s obzirom da je tehnologija u pogledu praćenja rada vozača i kretanja vozila toliko napredovala da nudi daleko više mogućnosti praćenja od tahograf uređaja, te posebno bitnu mogućnost da se praćenje putem tih uređaja može koristiti u svakom trenutku uz pregled svih željenih informacija o vozaču i vozilu, a sve po doslovno pristupačnim cijenama. Samim time mora se istaknuti da velik dio poslodavca koji u vozilima imaju ugrađene tahograf uređaje, koriste i uređaje za praćenje aktivnosti vozača i kretanja vozila. Iz navedenoga se može zaključiti da je u svojoj primjeni svaki od ovih uređaja zauzeo svoje mjesto. Tahograf uređaj u pogledu vođenja evidencije rada vozača, a uređaji za praćenje ulogu praćenja kretanja vozila i prikupljanja podataka o aktivnostima rada vozača, koje se uglavnom redovito automatski obrađuju i služe u svrhu određenih analiza.

\section{ZAKLJUČAK}

Iz navedenih i obrađenih izvora prava proizlazi da postoje vozači koji su izuzeti iz primjene pravila koja na specifičan način uređuju radno vrijeme, dozvoljeno vrijeme vožnje, obvezne odmore i evidenciju radnog vremena vozača te jednako tako da postoje i vozila kojima se obavljaju određeni poslovi koja su izuzeti i od same obveze ugradnje uređaja za bilježenje u cestovnom prijevozu tahografa, što samo po sebi olakšava organizaciju rada kao i izvršenje prijevozne usluge.

Sve to za sobom povlači manje obveza za vozače i poslodavce te manje troškove ukupnog poslovanja, što je vrlo bitno u sektoru cestovnog prijevoza putnika i dobara.

Sve dosad navedeno ni u kojem segmentu nema negativnih utjecaja na vozače, a samim time ni na sveukupnu sigurnost u cestovnom prometu.

Negativna je činjenica ta da još uvijek postoje određeni vozači koji su izuzeti od primjene posebnih pravila o radnom vremenu, obveznim odmorima mobilnih radnika i uređajima za bilježenje $u$ cestovnom prijevozu, a da vozila kojima obavljaju te poslove nisu izuzeta od obveze ugradnje 
tahograf uređaja, što samo po sebi navodi na to da izuzeti vozači prilikom upravljanja tim vozilima umeću tahograf listić u analogni tahograf uređaj, odnosno karticu vozača u digitalni tahograf uređaj te koriste funkciju „izvan nadležnosti“ (OUT). U cilju omogućavanja nesmetanog korištenja izuzeća u pogledu ugradnje tahograf uređaja u vozila čiji su vozači izuzeti od primjene pravila o radnom vremenu, obveznim odmorima mobilnih radnika i uređajima za bilježenje u cestovnom prijevozu trebalo bi izvršiti promjene u Pravilniku o tehničkim uvjetima vozila u prometu na cestama te isti uskladiti s izuzećima propisanim Zakonom o radnom vremenu, obveznim odmorima mobilnih radnika i uređajima za bilježenje u cestovnom prijevozu.

Nadalje, potrebna je veća angažiranost resornog ministarstva na promicanju prava i obveza vozača i poslodavaca - prijevoznika, a koja proizlaze iz svih relevantnih i specifičnih odredbi o radnom vremenu, obveznim odmorima mobilnih radnika i uređajima za bilježenje u cestovnom prijevozu, budući da postoji dobar dio vozača i poslodavaca koji nisu na odgovarajući način upoznati sa svojim pravima i obvezama. Tumačenja i mišljenja nadležnog ministarstva bi u tom smislu trebala biti što jasnija u pogledu prava i obveza vozača i prijevoznika, odnosno poslodavca. Jednako tako djelatnici Ministarstva unutarnjih poslova trebali bi biti bolje upoznati s važećim odredbama koje se odnose na radno vrijeme, vrijeme vožnje, obvezne odmore mobilnih radnika i uređaje za bilježenje u cestovnom prijevozu, s obzirom na to da i oni provode nadzor, a često puta imaju različite stavove i tumačenja u pogledu obveza vozača, koji završavaju na usmenim upozorenjima vozaču, dakle bez represivnih postupaka, ali za posljedicu imaju stvaranje zbunjenosti i nesigurnosti kod vozača i prijevoznika.

U cilju toga potrebno je pohvaliti uvođenje stavka 3. i posebno stavka 4. u članak 8. Zakona o radnom vremenu, obveznim odmorima mobilnih radnika i uređajima za bilježenje u cestovnom prijevozu, koji je jasno dao do znanja svakome čitatelju da se na vozače vozila koja su izuzeta u članku 13. stavku 1. Uredbe (EZ) br. 561/2006 primjenjuje zakon kojim se uređuju radni odnosi.

Ovaj dio zaključka prije svega zasniva se na tome da je dobar dio današnje vlasničke i upravljačke strukture u prijevozničkim tvrtkama nastao iz vozačkog kadra i to u trenutku kada se na području Republike Hrvatske nije pridavalo previše pažnje na provođenje propisa vezanih uz radno vrijeme, dozvoljeno vrijeme vožnje, obvezne odmore i evidenciju radnog vremena vozača, a od trenutka stupanja u položaj vlasnika prijevozničke tvrtke jednostavno su zaokupljeni aktivnostima na tržištu, pronalasku načina za nužno praćenje trendova napretka te samog opstanka na tržištu prijevoznih usluga.

\section{LITERATURA}

Bilić, A. (2017) „Fleksibilno radno vrijeme - modus rekoncilijacije privatnog i poslovnog života radnika te povećanja kompetitivnosti poslodavca“, Zbornik radova Pravnog fakulteta u Splitu, 54(3) p. 561- 585, https://hrcak.srce. $\mathrm{hr} / 186702$ (7. 1. 2018.)

Bjelinski Radić, I. (2017) „Novi oblici rada kao suvremeni izazov za radno pravo - slučaj Uber“, Zbornik Pravnog fakulteta Sveučilišta u Rijeci, 38(2) p.881-905, http://hrcak.srce.hr/index.php?show=clanak\&id_clanak_jezik=271821 (7. 1. 2018.) 


\section{Gočin, S. Debeljak: Izuzeća za vozaće i vozila - posebice u odnosu na prijevoz putnika... Zbornik Veleučilišta u Rijeci, Vol 6 (2018), No. 1, pp. 155-180}

Bodiroga-Vukobrat, N., Laleta, S., Jukić, A. (2008) „Posebnosti reguliranja radnog vremena u kontekstu Smjernice 2003/88/ EZ s osvrtom na nacionalna rješenja u Njemačkoj, Austriji i Hrvatskoj", Zbornik Pravnog fakulteta Sveučilišta u Rijeci, 29(1) p. 71-109, http://hrcak.srce.hr/index.php?show=clanak\&id_clanak_jezik=39987 (7. 1. 2018.)

Centar za vozila Hrvatske d.d. (2017) Obveza opremanja gradskih autobusa tahografom, Tahograf ispitan izvan Republike Hrvatske, dopis stanicama za tehnički pregled vozila, III/16, broj: 2503-01/2017., Zagreb, 30. 8. 2017.

Gočin, M., Debeljak, S. (2016) „Radno vrijeme i obvezni odmori mobilnih radnika, vozača, i praktični prikaz evidentiranja njihovih aktivnosti“, Zbornik Veleučilišta u Rijeci, 4(1) p. 123-146, http://hrcak.srce.hr/index. php?show=clanak\&id_clanak_jezik=236357 (3. 1. 2018.)

https://www.dzs.hr/Hrv_Eng/publication/2017/05-01-01_03_2017.htm (10.11. 2017.)

Kok et al. (2010) „A Dynamic Programming Heuristic for the Vehicle Routing Problem with Time Windows and the European Community Social Legislation“, Transporation Science, 44(4) p. 442-454, http://www.sfb637.uni-bremen. de/pubdb/repository/SFB637-B9-10-002-TR.pdf (5. 1. 2018.)

Meyer, C.M., Kopfer, H. (2008) „Restrictions for the operational transportation planning by regulations on drivers' working hours", In: Bortfeldt A. et al. Intelligent Decision Support. Wiesbaden: Gabler, https://link.springer.com/ chapter/10.1007/978-3-8349-9777-7_10 (5. 1.2018.)

Ministarstvo mora, prometa i infrastrukture (2017 a), Mišljenje, Klasa: 011-02/17-04/18, Ur. broj: 530-05-1-1-1-17-4, od 18. 5. 2017.

Ministarstvo mora, prometa i infrastrukture (2017 b), Mišljenje, Klasa: 011-01/17-01/152, Ur. broj: 530-07-17-1, od 21. 8. 2017.

Pavišić, B., Matiša, T. (2012) Komentar Zakona o sigurnosti prometa na cestama s prilozima, Rijeka: Libertin naklada

Pravilnik o radnom vremenu članova posade zrakoplova (NN 57/13)

Pravilnik o sadržaju i načinu vođenja evidencije o radnicima (NN 73/17)

Pravilnik o tehničkim uvjetima vozila u prometu na cestama (NN 85/16, 24/17)

Prescott-Gagnon, E. et al. (2010) „European Driver Rules in Vehicle Routing with Time Windows“, Transportation Science 44(4) p. 455-473, http://hanalog.polymtl.ca/wp-content/uploads/2016/09/GDR_vrptwDR_rev.pdf (3. 1. 2018.)

Rajsman, M., Rođak A. (2015) „Značenje tahografa u radu inspekcije cestovnog prometa i prevenciji prometnih nesreća“, Sigurnost, 57(1) p. 41-47, http://hrcak.srce.hr/index.php?show=clanak\&id_clanak_jezik=236357 (10. 1. 2018.)

Rožman, K. (2016 a) „Evidencija o radnom vremenu“, Radno pravo, 4/16 p. 3-7

Rožman, K. (2016 b) Radno vrijeme, Zagreb:Rosip d.o.o.

Tahografi u cestovnom prometu, Sažetci zakonodavstva EU-a, http://eur-lex.europa.eu/legal-content/HR/ LSU/?uri=CELEX:32014R0165 (20. 2. 2018.)

Učur, M. Đ., Smokvina, V. (2016) „Posebnosti radnopravnog statusa radnika u pomorskom ribarstvu s posebnim osvrtom na radno vrijeme i odmore", Naše more 63(4) pp. 98-106, http://hrcak.srce.hr/169937 (10. 12. 2017.)

Uredba (EU) br. 165/2014 Europskog parlamenta i Vijeća od 4. veljače 2014. o tahografima u cestovnom prometu, stavljanju izvan snage Uredbe Vijeća (EEZ) br. 3821/85 o tahografu u cestovnom prometu i izmjeni Uredbe (EZ) br. 561/2006 Europskog parlamenta i Vijeća o usklađivanju određenog socijalnog zakonodavstva koje se odnosi na cestovni promet (SL L 60, 28. 2. 2014)

Uredba (EZ) 561/2006 Europskog parlamenta i Vijeća od 15. ožujka 2006. o usklađivanju određenih socijalnih propisa vezanih uz cestovni prijevoz, a kojom se mijenjaju uredbe Komisije (EEZ) br. 3821/85 i (EZ) br. 2135/98, te kojom se ukida Uredba Vijeća (EEZ) br. 3820/85 (SL L 102/1, 11. 4. 2006)

Vrijeme vožnje $u$ sektoru cestovnog prometa, Sažetci zakonodavstva EU-a, http://eur-lex.europa.eu/legal-content/HR/LSU/?uri=CELEX:32006R0561 (22. 2. 2018.)

Zakon o prijevozu u cestovnom prometu (NN 82/13) 
M. Gočin, S. Debeljak: Izuzeća za vozaće i vozila - posebice u odnosu na prijevoz putnika... Zbornik Veleučilišta u Rijeci, Vol 6 (2018), No. 1, pp. 155-180

Zakon o radnom vremenu, obveznim odmorima mobilnih radnika i uređajima za bilježenje u cestovnom prijevozu (NN $75 / 13,36 / 15,46 / 17$ )

Zakon o radu (NN 93/14, 127/17)

Zakon o sigurnosti prometa na cestama (NN 67/08, 48/10, 74/11, 80/13, 158/13, 92/14, 64/15, 108/17)

Zakon o zračnom prometu (NN 69/09, 84/11, 54/13, 127/13, 92/14) 


\title{
EXEMPTIONS FOR DRIVERSAND VEHICLES - PARTICULARLY IN RELATION TO REGULAR PASSENGER TRANSPORT SERVICES AT A DISTANCE OF UP TO 50 KILOMETERS 3
}

\begin{abstract}
Exemptions from the application of certain provisions on working time, obligatory breaks for mobile workers and recording equipment in road transport applies to certain drivers who operate the excluded categories of vehicles and to vehicles which are partially or entirely exempted from the obligation to install a road vehicle recording device - a tachograph. Through this research, this paper answers the question what exactly the exemptions are, what law sources appertain to these exceptions, whether they apply in practice and what the novelties are in their practical implementation. The paper also explains the legal rules that determine the working hours and obligatory breaks of excluded drivers and how to keep records for such workers and their working hours. At the end of the paper, authors indicate advantages and disadvantages of applying these exemptions for both drivers and employers, and provide a concluding assessment of the benefits of these exemptions, as well as the need for additional interventions through acts, but even more, through practical knowledge of the rights and obligations of drivers and employers in order to overcome the vagueness and insecurities of these major participants in the transport of goods and passengers in road transport.
\end{abstract}

Key words: drivers, vehicles, regular services transport, exemptions, working hours, records

Bacc. ing. traff., Student, Polytechnic of Rijeka, Vukovarska 58, 51000 Rijeka, Croatia.

E-mail: predsjednik@sindikatvozaca.hr

2 PhD, Lecturer, Polytechnic of Rijeka, Vukovarska 58, 51000 Rijeka, Croatia. E-mail: sandra.debeljak@veleri.hr

3 Received: 15 January 2018; Accepted: 6 March 2018 